\title{
Production of a high-nutritional-value functional food, the Update1 bread, with the supplementation of the wheat flour with high-protein-content raw food materials
}

\author{
J. Csapó ${ }^{1,2}$ \\ N. Schobert ${ }^{3}$ \\ e-mail: csapo.janos@gmail.hu \\ e-mail: norbi@norbi.eu \\ ${ }^{1}$ University of Debrecen, Faculty of Agricultural and Food Sciences and \\ Environmental Management, Institute of Food Technology, \\ HU-4032 Debrecen, Böszörményi út 138., Hungary \\ ${ }^{2}$ Sapientia Hungarian University of Transylvania, \\ Faculty of Miercurea Ciuc, Department of Food Science, \\ RO-4100 Miercurea Ciuc, Piata Libertăţii 1., Romania \\ ${ }^{3}$ Norbi Update Lowcarb Zrt., HU-2016 Leányfalu, \\ Móricz Zsigmond utca 167, Hungary
}

\begin{abstract}
During our research, we added extracted soya bean meal, egg-white powder, gluten, wheat sourdough, and bamboo fibre to wheat flour in order to increase the quantity of the essential amino acid and the biological value of the wheat protein, producing such a functional, health-protecting, health-preservative food product which is suitable to satisfy the essential amino acid requirements of humans, assuming normal nutrition. Furthermore, we could produce such a food, which, on
\end{abstract}

Keywords and phrases: defatted soya bean meal, egg-white powder, gluten, supplementation, essential amino acids, biological value of protein, Maillard reaction, amino acid analysis, fortified bread with high essential amino acid content 
the one hand, was suitable to confine or prevent the essential amino acid's malnutrition symptoms, while, on the other hand, when applied alone, to meet the consumers' needs. During our work, we determined the protein content and amino acid composition of the wheat flour, of the additives used in bread baking, and in the bread both baked with supplementation (Update1 bread) and without supplementation (normal bread), as well as the quantity of the Maillard reaction products (hydroxymethylfurfural). We calculated the biological value of the protein of different breads and evaluated the sensory characteristics of the produced functional food and the fortified bread, supplemented with high essential-amino-acid-containing additives.

\section{Introduction}

Nowadays, there is an ever-growing interest about high-biological-value functional foods, while more and more articles are published in the groves of specialized literature on the impact of these functional foods regarding humans' diet and health. A great number of books, journals, and Internet sources treat this topic, and plenty of television programmes tackle the problem of disease prevention and treatment (Wildman, 2007). In recent years, the industrial sector of functional foods - including foods, beverages, and related and supporting sectors - has become one of the fastest growing branches of food industry. The drive of this sharp increase is fuelled not only by the group of health-conscious consumers but also by endemic diseases having to do with our civilized lifestyle (diabetes, obesity, or diseases affecting the nervous system and the digestive tract). In our time, we may still encounter many sceptical of the functional foods' beneficial effects, as these to take effect require regular consumption, and so their expected health benefits cannot be experienced instantaneously, but it may sometimes take months or even years.

In many countries of the developing world, the population is often grappling with protein deficiency due to the prevalence of low-protein-content plant foods. Protein deficiency can lead to growth retardation, oedema formation, and anaemia; if protein deficiency is coupled with lack of energy, malnutrition may cause the death of many infants and young children.

As a result of researches carried out in the past decades, today's subjectmatter is not the protein needs in general but the specific quantitative requirements in terms of the essential amino acids. Researchers have also revealed that we must not only cover the deficiencies in limiting amino acids but we must also aim at achieving a balanced ratio of essential amino acids. Moreover, 
we must pay close attention to obtaining an optimal ratio of essential/nonessential amino acids in our foods as well.

Once the industry-like production of amino acids had started, green light was given for amino acid supplementation, as a consequence of which a nearly optimal amino acid composition can be obtained, one of the methods leading up to producing protein of high biological value (Rossel et al., 2016; Albert et al., 2017a; Prokisch et al., 2017a). Due to the widespread application of amino acid analysis, the amino acid composition of many food ingredients has become common knowledge, and by combining them we can again produce foods, such as bread, with optimal ingredients - yet another way of producing foods of high biological value.

The reasonable selection of food ingredients makes it possible the use of such proteins that can supplement the limiting amino acids of staple foods, such as flour, therefore ensuring an optimal composition for the developing organism. Recently, besides data on amino acid requirements, the optimal and minimal protein levels are also provided. In case of a sufficient protein level, the energy surplus will facilitate the energy-intensive process of protein synthesis, increase weight gain, and enhance benefits and protein utilization (Rossel et al., 2016; Csapó \& Csapóné, 2007; Csapó et al., 2007).

\section{Literature review}

\subsection{Enhancing the nutritional value of wheat flour and wheat- flour-based products}

The protein needs of an adult person is $80-110 \mathrm{~g} /$ day depending on age and the exerted physical effort. In the case of a mixed diet, this amount of protein contains sufficient essential amino acids, but a one-sided diet may result in essential amino acid deficiency even if combined with an adequate protein consumption. Essential amino acids for an adult person include the following: isoleucine, leucine, lysine, methionine, phenylalanine, histidine, tryptophan, valine, and threonine (Csapó \& Csapóné, 2004).

Proteins that contain all essential amino acids in a sufficient amount and in an adequate proportion are called complete proteins. Such are the proteins of meat, egg, and milk. Plant-based proteins, however - compared to the needs -, lack lysine, methionine, threonine, and tryptophan to varying degrees. Since there may occur certain abnormalities in the vital functions of those consuming small amounts of complete proteins, they supplement the largely plant-based foodstuffs with the missing essential amino acids. This supplementation would 
be most needed in the case of cereal-based foodstuffs because the proteins of wheat and rye contain only small amounts of lysine, methionine, and threonine.

In Europe, people usually tend to opt for a supplementation with natural protein resources, for which the various soy-based products are the most suitable as soy protein contains a large amount of lysine and is stocked up with threonine above the average level. Its disadvantage is, however, the relatively low methionine and cystine content. Primarily, they used to fortify wheat-flour-based products - the efficiency of this protein supplementation is examined with the help of biological or chemical verification methods. Chemical methods can provide faster results, allowing us to determine the protein's amino acid composition and compare it to complete proteins by the calculation of chemical indices that give numerical information on the nutritional value of food proteins (Csapó \& Csapóné, 2006; Rossel et al., 2016).

The high lysine and threonine content of soya bean is an excellent supplement to the amino acid composition of the wheat flour, but an even better result can be obtained with a reasonably assorted protein supplementation, just as it happened in the case of the Update1 bread, where, besides soy protein, egg-white powder, gluten isolate, and dried yeast supplementation also took place. Due to protein supplementation, the carbohydrate content of wheat flour decreased by half, making this type of bread perfectly suited for the diet of diabetics and those who wish to lose weight.

\subsection{The use of high-biological-value protein and of lysine in flour enrichment}

The amount and ratio of amino acids in wheat is far from the optimal values necessary for the human organism, giving the nutritional value of wheat protein a score of approx. 53 on a scale of 100 . Since there is a low proportion of lysine first of all, the high-lysine-content materials are the most suitable for the amino acid enrichment of wheat flour (potato (biological value: 73) and soya bean (biological value: 74-78)).

As the regular consumption of foodstuffs made from cereals is a widely used practice in our days, people have long been engaged in using trace elements ( $\mathrm{Se}, \mathrm{Ca}, \mathrm{Cu}, \mathrm{Zn}, \mathrm{Fe}, \mathrm{P}$ ), vitamins (vitamin B family, vitamin E), proteins, and amino acids (tryptophan, lysine, threonine) in flour enrichment and fortification procedures.

Research on the clinical and dietetic application of L-lysine looks back to a history of 30-40 years. In 1976, Titcomb and Juers patented a type of bread with an amino acid composition corresponding to that of a complete protein. 
In producing it, besides applying various protein supplementations, L-lysine hydrochloride was added to the flour until reaching a $0.1-0.5 \%$ proportion. Mauron et al. (1976) added to wheat flour the $\varepsilon$-amino acyl derivative of lysine, which would later create lysine during deacylation in the organism. In order to achieve a balanced amino acid composition, aside from acyl-lysine, an approx. $0.1 \%$ of L-lysine hydrochloride was also added to the flour. El-Megged and Sands (1990) elaborated a procedure during which the lyophilized sample of a lysine-producing lactic acid bacteria strain was added to the leaven, thus enriching the amino acid composition.

On the average, there was a $0.2-0.5 \%$ addition of lysine to the flour in order to increase the protein content. Figueron et al. (2005) added $0.5 \%$ of lysine to the flour, while Muhammad et al. (2012) reported a $0.2-0.3 \%$ enrichment. Tajammal et al. (2004) employed a 0.5\% enrichment, yielding beneficial effects in children's development, increasing haemoglobin level in women, and elevating levels of transferrin in men. According to Karcz (2004), the consumption of $325 \mathrm{~g}$ of bread/day is recommended to satisfy $25 \%$ of people's daily needs of lysine.

Wenhua et al. (2004) conducted an experiment where the subjects consumed flour-based bread fortified with $0.3 \%$ of lysine, for a period of 3 months. They found that the consumption of lysine-enriched bread had positive effects on the immune system; although the haemoglobin level does not increase, the $0.3 \%$ lysine improves the immune system due to its effect on $\operatorname{IgA}, \operatorname{IgB}$, and $\mathrm{IgE}$.

Several research results confirm the beneficial effects of lysine-enriched flours: Anton et al. (2008) and Mora Aviles et al. (2007) studied the effects of bean meal supplementation in tortilla, Tyagi et al. (2007) investigated the effects of mustard flour in rusk, while Lindenmeier and Hofmann (2004) looked into how a lysine derivative affects baking properties.

During a careful examination of the relevant literature, we did not come across any researcher who would have applied extracted soya bean meal, eggwhite powder, and gluten or dried yeast in combination to produce bread with a low carbohydrate and high protein content, in which there would have been an outstanding essential amino acid ratio in the protein due to the extracted soya bean meal. 


\subsection{The physiological effects of the high lysine content of Up- date1 bread}

It has been known for long that in the absence of L-lysine - the essential amino acid making up our proteins -, dietary calcium cannot get to the bones, and the synthesis of a number of proteins will also be inhibited. L-lysine plays a fundamental role in the formation of collagen that makes up the organic substance of the bone and skin, but its effect in strengthening the immune system and combatting viruses is also confirmed.

With respect to bone metabolism and the prevention of osteoporosis, the consumption of calcium, phosphorus, and vitamin $\mathrm{D}$ have been for long in the focus of literature as primary nutritional factors although vitamin $\mathrm{C}$ and lysine are also crucial in the formation of collagen making up the organic substance of the bones. Vitamin $\mathrm{C}$ takes part in the activation of vitamin $\mathrm{D}$, on the one hand, and converts lysine, which takes part in building up the collagen substance of the bone, into a form suitable for the creation of procollagen, on the other hand. Research findings corroborate that, besides vitamin C, Llysine is also a major contributor to the formation of a healthy bone structure (Civitelli et al., 1992).

Pauling (1991) reported on the beneficial effects of lysine and vitamin C on the vascular system and on coronary artery diseases. Rath (2001) developed a product suitable for treating diseases related to the impairment of the extracellular matrix (atherosclerosis, cancer, infection, or other inflammatory diseases). The product contained lysine, proline, ascorbate, and their derivatives and synthetic analogues as well as vitamins, provitamins, and trace elements. In their study on L-lysine and the reaction of various carbohydrates, Kitts and $H u$ (2005) demonstrated that Maillard reaction products showed a significant antioxidant activity.

In summary, we can state that L-lysine intake in any form increases the biological value of lysine-deficient proteins, contributes to the optimal development of the young organism, and, besides its many therapeutic effects, can be effectively applied in fighting for the preservation of health.

\subsection{The role of lysine in the formation of Maillard reaction products}

Monosaccharides, reducing carbohydrates in general, with free amino group, react with each other under appropriate conditions, and by this reaction aroma compounds and brown-coloured pigments, so-termed melanoidins, are created. 
This process is called the Maillard reaction. In the production of lysine-content bakery goods - as the $\varepsilon$-amino group of lysine is extremely sensitive to the Maillard reaction -, during the non-enzymatic browning reaction conducted at an appropriate temperature, antioxidants as well as colour and flavour substances are created, which contribute to the health-protective effect (Csapó et al., 2006).

However, in planning the composition of the ingredients, we must also consider that the products resulting from high lysine content may spoil the product's palatability traits since the large amount of Maillard reaction products may come with unwanted flavour and colour effects (Csapó\&Csapóné, 2006, 2007). We may say bread is a fortunate solution as temperature never rises above $100{ }^{\circ} \mathrm{C}$ on the inside, while in the bread-crust there is a proportionally low amount of lysine.

\subsection{Humans' protein and amino acid requirements}

The establishment of humans' protein requirements must take account of the protein loss in case of appropriate energy intake and a protein-free diet. This loss of endogenous protein is excreted from the body through urine, faecal matter, and perspiration, its amount also being enhanced by the wearing out of the skin, the growing hair and nails. On average, endogenous protein loss is approximately $0.34 \mathrm{~g}$ per body mass kilogram. Adult individuals' protein requirements can be satisfied with $0.75 \mathrm{~g}$ of good-quality protein per body mass kilogram, whereas in the case of infants, children, expectant and nursing mothers protein requirements are higher as the developing organism has to be provided with the necessary amount of protein for a proper growth and development (in the former two cases), but the protein needs of the foetus and of breast milk production must also be met (in the latter two cases). Table 1 includes WHO data in relation to age on the safe amounts of protein intake when consuming milk or egg-white.

Naturally, the human body does not utilize protein itself but the amino acids found therein. For humans, histidine (depending on age), isoleucine, leucine, lysine, methionine, phenylalanine, threonine, tryptophan, and valine are all essential. Cystine, produced from methionine, and tyrosine, produced from phenylalanine, are semi-essential amino acids. In a healthy human body, intestinal microorganisms can synthesise histidine, wherefore amino acid is essential only for infants as the synthesised amount found in the intestines is perfectly sufficient for adult people's needs (Csapó et al., 2007). Table 2 includes the WHO recommendations on infants', young children's, and adults' 
estimated amino acid requirements.

Table 1: Safe protein intake values $(\mathrm{g} / \mathrm{BMkg})$ for children according to the WHO recommendations

\begin{tabular}{cccc}
\hline Age (year) & Protein (g/BMkg) & Age (year) & Protein (g/BMkg) \\
\hline \multicolumn{3}{c}{ Girls and boys together } & \multicolumn{3}{c}{ Girls } \\
$0.25-0.5$ & 1.86 & $10-11$ & 1.00 \\
$0.50-0.75$ & 1.65 & $11-12$ & 0.98 \\
$0.75-1.00$ & 1.48 & $12-13$ & 0.96 \\
$1.00-1.50$ & 1.26 & $13-14$ & 0.94 \\
$1.50-2.00$ & 1.17 & $14-15$ & 0.90 \\
$2-3$ & 1.13 & & Boys \\
$3-4$ & 1.09 & & \\
$4-5$ & 1.06 & $10-11$ & 0.99 \\
$5-6$ & 1.02 & $11-12$ & 0.98 \\
$6-7$ & 1.01 & $12-13$ & 1.00 \\
$7-8$ & 1.01 & $13-14$ & 0.97 \\
$8-9$ & 1.01 & $14-15$ & 0.96 \\
$9-10$ & 0.99 & & \\
\hline
\end{tabular}

$\mathrm{BMkg}=$ body mass kilogram

Table 2: Estimated amino acid requirements based on the WHO recommendations (mg/BMkg/day)

\begin{tabular}{lcccc}
\hline \multicolumn{1}{c}{ Amino acid } & $\begin{array}{c}\text { Infants } \\
(3-4 \text { months })\end{array}$ & $\begin{array}{c}\text { Young children } \\
(2 \text { years })\end{array}$ & $\begin{array}{c}\text { School children } \\
(10-12 \text { years })\end{array}$ & Adults \\
\hline Histidine & 28 & - & - & - \\
Isoleucine & 70 & 31 & $28-30$ & 10.0 \\
Leucine & 161 & 73 & $44-45$ & 14.0 \\
Lysine & 103 & 64 & $44-60$ & 12.0 \\
Methionine + cystine & 58 & 27 & $22-27$ & 13.0 \\
Phenylalanine + & 125 & 69 & $22-27$ & 14.0 \\
tyrosine & & & & \\
Threonine & 87 & 37 & $28-35$ & 7.0 \\
Tryptophan & 17 & 12.5 & $3.3-4.0$ & 3.5 \\
Valine & 93 & 38 & $25-33$ & 10.0 \\
Total & 742 & 352 & $216-261$ & 84.0 \\
\hline
\end{tabular}


Table 3 includes the optimal amount of amino acids in protein intake, based on the WHO recommendations, in comparison with the amino acid composition of wheat, soya, and egg protein. Nevertheless, data shown in this table may vary according to each individual's physical abilities, state of health, and due to several other reasons. Generally speaking, the average protein requirement is $0.6 \mathrm{~g} / \mathrm{BMkg}$, while the lowest amount of daily protein intake must not go below $0.45 \mathrm{~g}$ per BMkg.

Table 3: The optimal protein amino acid composition for infants, children, and adults in comparison with the amino acid composition of wheat, soya, and egg protein, based on the WHO recommendations

\begin{tabular}{|c|c|c|c|c|c|c|c|}
\hline \multirow[b]{2}{*}{ Amino acid } & \multicolumn{7}{|c|}{ Amino acid, mg/g protein } \\
\hline & $\begin{array}{l}\text { Infants - } \\
\text { average* }\end{array}$ & $\begin{array}{l}2-5 \text { years } \\
- \text { children }\end{array}$ & $\begin{array}{l}\text { 10-12 years } \\
\text { - children }\end{array}$ & Adults & Wheat & Soya & Egg \\
\hline Histidine & 26 & 19 & 19 & 16 & 23 & 32 & 22 \\
\hline Isoleucine & 46 & 28 & 28 & 13 & 40 & 41 & 54 \\
\hline Leucine & 93 & 66 & 44 & 19 & 71 & 77 & 86 \\
\hline Lysine & 66 & 58 & 44 & 16 & 30 & 61 & 70 \\
\hline $\begin{array}{l}\text { Methionine }+ \\
\text { cystine }\end{array}$ & 42 & 25 & 22 & 17 & 41 & 31 & 57 \\
\hline $\begin{array}{l}\text { Phenylalanine }+ \\
\text { tyrosine }\end{array}$ & 72 & 63 & 22 & 19 & 78 & 88 & 93 \\
\hline Threonine & 43 & 34 & 28 & 9 & 32 & 40 & 47 \\
\hline Tryptophan & 17 & 11 & 9 & 5 & 12 & 16 & 17 \\
\hline Valine & 55 & 35 & 25 & 13 & 48 & 47 & 66 \\
\hline \multicolumn{8}{|l|}{ Total } \\
\hline with histidine & 460 & 339 & 241 & 127 & 375 & 433 & 512 \\
\hline without histidine & 434 & 320 & 222 & 111 & 352 & 401 & 490 \\
\hline
\end{tabular}

*Estimated values based on the amino acid composition of mother's milk.

How can the main components of wheat protein meet these requirements? In terms of lysine, this is very difficult to accomplish since cereal proteins contain a relatively low amount of lysine. Among wheat proteins, albumins contain almost all proteinogenic amino acids. Their isoelectric point is about $\mathrm{pH}=$ 4-5. Globulins usually occur together with albumins, and their separation is possible based upon molecular mass. Globulins dissolve in dilute saline and some of them also in distilled water. These latter are called pseudoglobulins in contrast to euglobulins, which dissolve in dilute saline. A high concentration of proline and glutamic acid is peculiar to prolamins - they do not contain any lysine. Gliadin and glutenin together form the complex protein of gluten, which is a key protein in wheat noodle production. Glutenins are typical plant proteins found in seeds. Arginine, proline, and glutamic acid 
are predominantly present in their amino acid composition; the best known variant is the glutenin found in wheat. Thus, the amount of lysine is low in cereal crops $(2-4 \%)$, which is a limiting factor for the biological value of many proteins of plant origin.

Under normal nutritional conditions, there is no risk of lysine overnutrition. If, however, an amount of lysine in excess of actual needs gets into the system, it will be utilized as energy (Csapó and Csapóné, 2007).

\section{Aims of the experiments}

The aim of our research is to produce a type of bread as a functional food, fortified with lysine and other essential amino acids, which helps in satisfying the organism's optimal essential amino acid needs and has beneficial effects in the treatment of osteoporosis and other diseases of the circulatory system. We expect that adding a right dosage of extracted soya bean meal, egg-white powder, gluten, and dried yeast to wheat flour will increase the amount of essential (and, in the case of wheat flour, limiting) lysine as well as the biological value of wheat protein, whereas that adding an amount higher than necessary for increasing the biological value will result in such a functional, health-protective, and health-preserving product that will help prevent diseases caused by amino acid deficiency, such as weakness of the bones or osteoporosis.

As during the baking process bread-crumb temperature does not exceed $100{ }^{\circ} \mathrm{C}$, we were hoping for a practically unchanged lysine content inside the bread, while in the bread-crust and directly underneath of it lysine would be transformed in significant quantities into colour and flavour substances (Maillard reaction) as well as antioxidants. We were also confident that the application of egg-white powder and dried yeast would let us introduce those essential amino acids into the bread that can be found in relatively small amounts in soya bean (methionine, cystine). The sole purpose of applying gluten was to increase protein content and decrease carbohydrate content, while the added bamboo fibre also served to decrease the starch content and increase fibre content.

In summary, the point of our solution is to produce a type of bread with a complete amino acid composition, high essential amino acid content, increased protein and fibre content, and reduced starch content. Therefore, we mixed together wheat flour of $12-13 \%$ protein content with egg-white powder of $83 \%$ protein content, gluten of $79.4 \%$ protein content, extracted soya bean flour of $49.3 \%$ protein content, dried yeast of $16 \%$ protein content, and the practically 
protein-free bamboo fibre so that we could obtain a flour of high biological value suitable for the production of functional foods and also having healthprotective and health-preserving effects. In this article, we report on our research results regarding the Update1 bread.

\section{Materials and methods}

\subsection{Composition of the basic ingredients for bread and the baking process}

In planning the composition of the ingredients, we had to consider the amino acid content of the ingredients and of the end-product, the relative proportion of the amino acids, and the balanced volume of non-essential amino acids next to the essential amino acids. We had to pay attention and avoid at all costs the unwanted flavour and colour effects of the large amount of Maillard reaction products due to the increased lysine content.

The raw mixture was composed of wheat flour of $12-13 \%$ protein content, egg-white powder of $83.0 \%$ protein content, gluten of $79.4 \%$ protein content, extracted soya bean flour of $49.3 \%$ protein content, dried yeast of $16 \%$ protein content, and the practically protein-free bamboo fibre. The percentage composition of the mixture is protected by patent, and therefore we cannot disclose it. Following the baking process, during which we applied special temperature and timing combinations, we examined all attributes of the breads that are also applied in practice upon the evaluation of breads. Throughout the pilot production phase - depending on the nature of the product -, the dough was leavened, shaped, and then baked in an automatic bread-baking machine. With the preliminary results in hand, we adjusted baking temperature and time as required, depending on whether we intended to produce a bread with higher lysine or higher antioxidant content.

\subsection{Chemical-analytical investigations}

\subsubsection{Determination of total protein and amino acid composition}

Prior to analytical investigations, we let the bread dry at room temperature, milled it to the fineness of flour, and used this homogeneous material in our examination. The total protein content of the breads was determined with the help of VelpScientifica UDK 159, an apparatus operating on the principle of the Kjedahl method. The protein was hydrolysed with $6 \mathrm{M} \mathrm{HCl}$ at $110^{\circ} \mathrm{C}$ for 
$24 \mathrm{hrs}$, and the determination of amino acids was carried out with the highperformance liquid chromatography method with orto-phthalaldehyde (OPA)2-mercaptoethanol pre-column derivatization. Apparatus used: Varian Pro Star; method applied: fluorescence detection $(\lambda \mathrm{ex}=340 \mathrm{~nm}, \lambda \mathrm{em}=455 \mathrm{~nm})$; column: Pursuit C18 $5 \mu \mathrm{m}, 250 \times 4.6 \mathrm{~mm}$; gradient elution: A: $100 \mathrm{mmol} / \mathrm{l}$ acetate puffer $(\mathrm{pH}=6.95) 925 \mathrm{ml}$, methanol $50 \mathrm{ml}$, tetrahydrofuran $25 \mathrm{ml}$, $\mathrm{B}$ : methanol $975 \mathrm{ml}$, tetrahydrofuran $25 \mathrm{ml}$; flow rate: $0.8 \mathrm{ml} / \mathrm{min}$; gradient program for the analysis: 0-8 min; A component $100 \%$, B component $0 \%, 8$ 11 min: $90-10,11-16$ min: $75-25,16-20 \mathrm{~min}: 60-40,20-24 \mathrm{~min}: 60-40,24-27$ min: 40-60, 27-32 min: 0-100, 32-33 min: 0-100, 33-47 min: 100-0. Under the conditions employed, there was a fairly clear separation of the amino acids, while quantification was not disturbed by any circumstances.

In the determination of tryptophan, the protein was hydrolysed with $4 \mathrm{M}$ sodium hydroxide at $110^{\circ} \mathrm{C}$ for $24 \mathrm{hrs}$, and then we determined tryptophan content using once again the high-performance liquid chromatography method.

\subsubsection{Determination of HMF}

In order to estimate the amount of Maillard reaction products, high-performance liquid chromatography was used to determine the hydroxymethylfurfural (HMF) concentration of the bread. For the measurement of HMF, samples taken from the different types of bread were ground in electric mill to 0.75 $\mathrm{mm}$ sieve size. An amount of $1 \mathrm{~g}$ was taken from each sample, to which we added $9 \mathrm{ml}$ of de-ionized water, and then we had it mixed with a Vortex tube mixer. Following this, with a view to eliminate any interfering substances, $0.5 \mathrm{ml}$ of Carrez I and Carrez II solution was added to the extract, and then centrifuged for 10 minutes at 5,000 rpm. The supernatant was removed and filtered through $0.45 \mu \mathrm{m}$ filtration hoods, and $20 \mu \mathrm{l}$ of the obtained solution was injected into the Varian Pro Star HPLC apparatus. Isocratic elution method was used to measure HMF, where the mobile phase was a 20:80\% solution of $5 \%$ methanol-acetic acid, the stationary phase was Pursuit C18 column $(250 \times 45 \mathrm{~mm})$, the rate flow was $1 \mathrm{ml} / \mathrm{min}$, and UV detection was performed at a wavelength of $285 \mathrm{~nm}$.

\subsubsection{Calculating the biological value of the protein}

Determination of protein quality starts with determining protein content, followed by determining the amino acid composition of the protein. Data on amino acid composition let us determine the limiting amino acid of the pro- 
tein as compared to the amino acid composition of the reference protein made according to the FAO/WHO recommendations. The amino acid occurring in the lowest percentage is the limiting amino acid, whose numerical value is the chemical index (CS). Besides CS, other indices can also be calculated from the amino acid composition if we consider the rest of the essential and non-essential amino acids as well.

Nowadays, during the determination of biological value in human terms, many tend to use the Morup and Olesen (1976) biological value calculation method, who, based on their experiments carried out with young male university students, experienced the highest rate of nitrogen retention when the experimental subjects were consuming a mixture made up of $66 \%$ potato and $34 \%$ whole egg, which in our country is mostly similar to layered potato casserole of a very good quality, prepared without sausages. They elaborated the following equation for the calculation of biological value: where:

Biological value $=10^{2.15} \cdot q_{\text {Lys }}^{0.41} \cdot q_{\text {Arom }}^{0.60} \cdot q_{\text {Sulf }}^{0.77} \cdot q_{\text {Thr }}^{2.41} \cdot q_{\text {Trp }}^{0.21}$,

$q=a / a_{r e f}$,

$a=a$ particular essential amino acid/all essential amino acids in the protein under examination,

$a_{r e f}=a$ particular essential amino acid/all essential amino acids in the reference protein,

Arom $=$ aromatic amino acids (Tyr, Phe),

Sulf $=$ sulphur-containing amino acids (Cys, Met).

According to this, the biological value of the reference protein is $10^{2.15} \cdot 1$. $1 \cdot 1 \cdot 1 \cdot 1$, that is $=141.25$. When calculating the biological value, aromatic amino acids (phenylalanine + tyrosine) and sulphur-containing amino acids (methionine + cystine) were evaluated together besides lysine, threonine, and tryptophan.Among amino acids, tryptophan figures on the 0.21 power, and thus it has the lowest influence on biological values, while threonine figures on the 2.41 power, having the highest influence on biological value. As for the rest of the amino acids, this index varies between 0.41 and 0.77 , thus exerting by and large a similar degree of influence on biological value.

\subsection{Sensory analysis}

During the sensory analysis of the breads, we evaluated their shape (typical of bread (loaf shape), regular, proportionately convex, not deformed), crust (typ- 
ical of the particular type of bread; shiny, smooth or cracked; scattered and/or sliced; not split all the way, not sooty/soiled/burned/saturated/damaged), internal content (baked thoroughly; does not separate from the crust; the colour is typical of the flour used; the substance is consistent, flexible, and free of lumps; not lardy, sticky, crumbly, or falling apart; does not contain foreign substances), as well as taste and aroma (aromatic - typical of the particular type of bread, not having strange taste or odour). Sensorial analyses were carried out as prescribed by Codex Alimentarius (2004).

\subsection{Statistical evaluation of the data}

We used Microsoft Excel 2010 software package and one-way analysis of variance to perform the statistical evaluation of the data.

\section{Results and discussion}

\subsection{Protein content and amino acid composition of bread in- gredients}

To determine the total protein content, the samples taken from the different types of bread were ground in electric mill to $0.75 \mathrm{~mm}$ sieve size and passed through a sieve with such hole size, and then an amount of $2 \mathrm{~g}$ from the wheat flour and - due to the higher protein content $-1 \mathrm{~g}$ from the other ingredients were digested. Digestion and distillation of ammonia were equally repeated three times.

Prior to determining the essential amino acids, the proteins of wheat flour and of the ingredients were hydrolysed with $6 \mathrm{M} \mathrm{HCl}$ at $110^{\circ} \mathrm{C}$ for $24 \mathrm{hrs}$, and then, after proper dilution and derivatization, $20 \mu \mathrm{l}$ of hydrolysate was injected into the high-performance liquid chromatography. In the determination of tryptophan, the protein was hydrolysed with $4 \mathrm{M}$ sodium hydroxide at $110^{\circ} \mathrm{C}$ for $24 \mathrm{hrs}$, and then we determined tryptophan content using once again the high-performance liquid chromatography method.

The protein content of wheat and the wheat flour produced from it varies between $11 \%$ and $14 \%$ depending on the species and growing conditions. Among its protein fractions, albumins are water soluble, globulins are soluble in 0.4 $\mathrm{mol} / \mathrm{l} \mathrm{NaCl}$ saline, prolamins are soluble in $70 \%$ aqueous ethanol solution, and glutenins form the fraction remaining from the flour after the sequential extraction. Upon dissolving the glutenins in $60 \%$ aqueous solution of 1-propanol, the high-molecular-weight (HMW) subfraction precipitates, whereas the low- 
molecular-weight (LMW) subfraction remains in the solution. Enzymes can be ranked among albumin and globulin fractions, while prolamins and glutelins form the category of storage proteins. In wheat, the albumin fraction amounts to $14.7 \%$ of the total protein, the globulin $7 \%$, the prolamin $32.6 \%$, and the glutelin $45.7 \%$. In the case of wheat, the albumin is termed leucosine, globulin is edestin, prolamin is gliadin, and glutelin is glutenin.

Low lysine and methionine content is characteristic of the amino acid composition of cereal crops - wheat contains an especially low amount of methionine.100 g of wheat (with $13.2 \%$ protein content) contains $0.73 \mathrm{~g}$ aspartic acid, $0.42 \%$ threonine, $0.69 \%$ serine, $3.75 \%$ glutamic acid, $1.36 \%$ proline, $0.55 \%$ glycine, $0.53 \%$ alanine, $0.32 \%$ cystine, $0.63 \%$ valine, $0.22 \%$ methionine, $0.53 \%$ isoleucine, $0.94 \%$ leucine, $0.42 \%$ tyrosine, $0.61 \%$ phenylalanine, $0.30 \%$ histidine, $0.40 \%$ lysine, $0,65 \%$ arginine, and $0.16 \%$ tryptophan.

Wheat gluten (with $79.4 \%$ protein content) contains $4.4 \%$ aspartic acid, $2.8 \%$ threonine, $4.8 \%$ serine, $31.9 \%$ glutamic acid, $12.1 \%$ proline, $3.5 \%$ glycine, $2.4 \%$ alanine, $1.8 \%$ cystine, $4.6 \%$ valine, $1.7 \%$ methionine, $4.1 \%$ isoleucine, $7.2 \%$ leucine, $3.1 \%$ tyrosine, $4.7 \%$ phenylalanine, $2.3 \%$ lysine, $1.8 \%$ histidine, $3.9 \%$ arginine, and $1.1 \%$ tryptophan. Its amino acid composition predominantly includes glutamic acid and proline, these two non-essential amino acids amounting to $44.0 \%$ of the total protein content.

The other main ingredient of Update1 flour is extracted soya bean meal with $49.3 \%$ protein content. $60 \%$ of the mass of the soya bean is made up of protein and oil, approx. 35\% carbohydrates, and the remaining 5\% is ash. Most part of the protein is heat-resistant, which is a significant factor since procedures aiming at reducing or eliminating trypsin inhibitor activity involve heat treatment, which does not damage soya protein provided a proper technology is applied. Carbohydrates of soya bean include saccharose, raffinose, and stachyose, indigestible to humans but still useful for their water-binding properties as they protect seeds from desiccation. Its insoluble carbohydrates include cellulose, hemicellulose, and pectin, also indigestible to humans but with significant beneficial physiological effects. The oil content of soya bean will not be discussed here as the production of the Update bread made use of extracted soya bean flour, which contains only traces of oil.

Its mineral content is approx. $5 \%$ including a significant amount of macroelements (potassium, calcium, magnesium, and phosphorus) and microelements (mostly zinc and iron). It contains a considerable amount of B-group vitamins (pantothenic acid, pyridoxine, folic acid, thiamine, niacin, and riboflavin) as well as vitamins $\mathrm{E}$ and $\mathrm{K}$. Its vitamin $\mathrm{C}$ content is negligible.

Its protein content ranges between $36 \%$ and $37 \%$, while the protein content 
of the extracted soya bean meal can reach 50\%. $100 \mathrm{~g}$ of mature, air-dry soya bean contains $5.10 \mathrm{~g}$ aspartic acid, $1.77 \mathrm{~g}$ threonine, $2.36 \mathrm{~g}$ serine, $7.87 \mathrm{~g}$ glutamic acid, $2.38 \mathrm{~g}$ proline, $1.88 \mathrm{~g}$ glycine, $1.93 \mathrm{~g}$ alanine, $0.66 \mathrm{~g}$ cystine, 2.03 $\mathrm{g}$ valine, $0.55 \mathrm{~g}$ methionine, $1.97 \mathrm{~g}$ isoleucine, $3.31 \mathrm{~g}$ leucine, $1.54 \mathrm{~g}$ tyrosine, $2.12 \mathrm{~g}$ phenylalanine, $2.71 \mathrm{~g}$ lysine, $1.10 \mathrm{~g}$ histidine, $3.15 \mathrm{~g}$ arginine, and 0.59 $\mathrm{g}$ tryptophan. If we multiply the values by two, we will get the amino acid content of the soya protein.

The third main component of Update1 bread is egg-white powder. Except for fibre, egg contains almost all valuable nutrients. The biological value of its protein is perhaps the highest among all food proteins, which is why it may be considered a protein that serves as a reference base in the calculation of other proteins' biological value. Its yolk contains large amounts of fats and vitamins; this way, the egg white and egg yolk together can meet human requirements almost optimally. Therefore, if properly prepared and without changing its composition, it can be considered a functional food.In summary, egg is rich in nutrient content, being one of the most valuable naturally created foods. It has great versatility in its industrial and home use, and besides the hen's egg our diet also includes the eggs of duck, goose, lapwing, seagull, and quail. Egg white is a $10 \%$ aqueous solution of proteins, which, aside from proteins, also contains $0.03 \%$ lipids and $1 \%$ carbohydrates. The $\mathrm{pH}$ of a fresh egg is between 7.6 and 7.9 , which can go up to 9.7 during storage time as the soluble $\mathrm{CO}_{2}$ diffuses from the egg through the eggshell. $\mathrm{pH}$ increase is a timeand temperature-dependent procedure. At $35^{\circ} \mathrm{C}$ in 21 days, $\mathrm{pH}$ increases to 9.4. Albumin proteins with a biological activity provide protection against microbial degradation. In this manner, for instance, cleaving the peptidoglycans that form the bacterial cell walls, lysozyme enzyme kills the bacteria, while enzyme inhibitors (ovomucoid, ovoinhibitor) and substances forming complexes with the coenzymes (e.g. flavoprotein, avidin) also play the same role.

$100 \mathrm{~g}$ of egg white contains $6.0 \mathrm{~g}$ aspartic acid, $3.4 \mathrm{~g}$ threonine, $6.0 \mathrm{~g}$ serine, $10.9 \mathrm{~g}$ glutamic acid, $2.9 \mathrm{~g}$ proline, 2.9 glycine, $5.5 \mathrm{~g}$ alanine, $1.9 \mathrm{~g}$ cystine, $6.0 \mathrm{~g}$ valine, $3.0 \mathrm{~g}$ methionine, $5.0 \mathrm{~g}$ isoleucine, $6.8 \mathrm{~g}$ leucine, $3.2 \mathrm{~g}$ tyrosine, $4.9 \mathrm{~g}$ phenylalanine, $4.6 \mathrm{~g}$ lysine, $1.7 \mathrm{~g}$ histidine, $4.5 \mathrm{~g}$ arginine, and $1.2 \mathrm{~g}$ tryptophan.

The dried yeast with $16 \%$ protein content used in bread baking is so small in quantity compared to the above-listed components that it has no effect whatsoever on the amino acid composition of the flour and that of the bread produced from it.

Based on measurement data, we can establish that Update1 flour is a flour mixture of high protein and fibre content and reduced carbohydrate content, 
produced from natural ingredients, being sufficient of itself to be used in the preparation of various products with reduced carbohydrate content (e.g. breads, bakery products, desserts, pastries, muffins, etc.). It might be a convenient solution for those who do not like to experiment with the proportions. It contains fine-ground wheat flour, defatted soya bean flour, wheat gluten, dried yeast, bamboo fibre, and soya protein isolate. According to official data, its caloric value is $1364 \mathrm{~kJ} / 100 \mathrm{~g}$, its fat content $1.4 \%$, of which the saturated fatty acid less than $0.5 \%$, its carbohydrate content $35.4 \%$, of which sugar $2.8 \%$, starch $32.6 \%$, fibre $14.4 \%$, protein $35.0 \%$, and salt $0.125 \%$. Overall, it can be said this is a natural food ingredient with a protein content almost three times the fine-ground flour and a carbohydrate content decreased by half.

\subsection{Total protein content of the bread}

To determine the total protein content, the samples taken from the different types of bread were ground in electric mill to $0.75 \mathrm{~mm}$ sieve size, and an amount of $2 \mathrm{~g}$ from the regular bread and - due to the higher protein content $-1 \mathrm{~g}$ from the Update1 bread were digested. Digestion and distillation of ammonia were equally repeated three times. We measured the following amounts of protein content: control bread $-12.4 \pm 0.18 \%$, Update1 bread $-35,2 \pm 0,26 \%$. Results immediately make it clear that due to the added extracted soya bean flour, egg-white powder, and gluten, the protein content of the Update1 bread has increased 2.86 times compared to the control bread. This increase was an expected outcome as all of the additives had a higher protein content than the wheat flour.

\subsection{Essential amino acid composition of the control and the Update1 bread}

Prior to determining the essential amino acids, the proteins of the breads were hydrolysed with $6 \mathrm{M} \mathrm{HCl}$ at $110^{\circ} \mathrm{C}$ for $24 \mathrm{hrs}$, and then, after proper dilution and derivatization, $20 \mu \mathrm{l}$ of hydrolysate was injected into the high-performance liquid chromatography. In the determination of tryptophan, protein was hydrolysed with $4 \mathrm{M}$ sodium hydroxide at $110^{\circ} \mathrm{C}$ for $24 \mathrm{hrs}$, and then we determined tryptophan content using once again the high-performance liquid chromatography method. Table 4 includes the essential amino acid content of wheat flour, extracted soya bean meal, egg-white powder, gluten, control bread, and the Update1 bread as well as the biological value of the protein. 


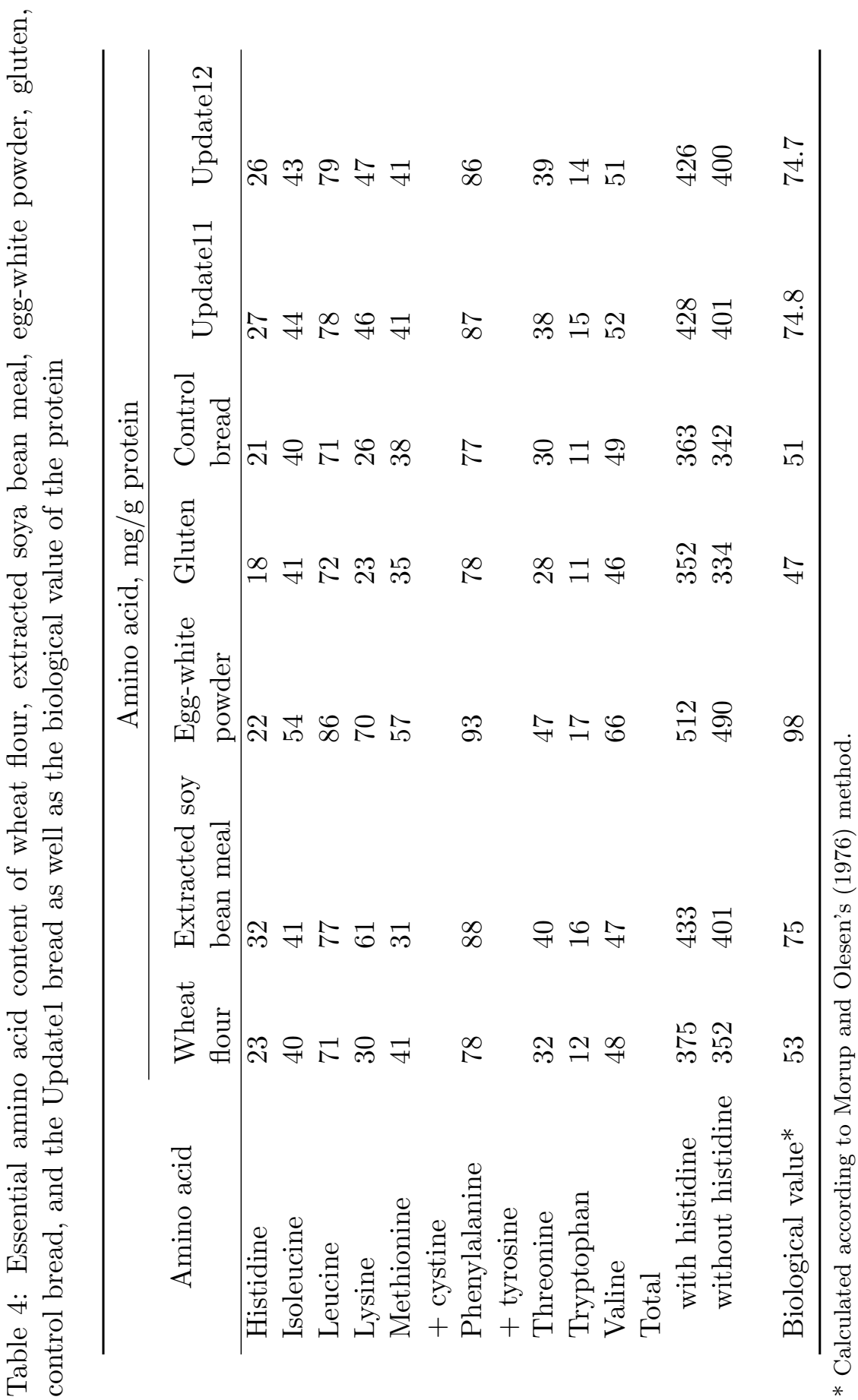


As it can be seen from the table, wheat flour and gluten contain the smallest amounts of essential amino acids among the applied ingredients, yielding therefore the lowest biological value for the protein of wheat flour (53) and gluten (47). The high lysine and threonine content of the extracted soya bean meal is in line with expectations, but its sulphur amino acid content is rather moderate, and so the biological value of the protein is 75 . Due to its outstanding essential amino acid content, egg white disposes of the highest biological value (98), and thanks to its high methionine and cystine content it serves as an excellent supplement to the low levels of sulphur amino acids in the soya and wheat protein as well as in gluten. The high lysine and, especially, threonine content of egg white also contributes to the high biological value of the Update1 bread for which it serves as a supplement. Owing to its low lysine, threonine, and sulphur amino acid content, gluten has the lowest biological value.

As a consequence of the amino acid composition of the additives used during dough preparation and due to the baking processes, the control bread has practically the same level of amino acid content as wheat flour, but because of a minimal loss of lysine, methionine, and cystine, its biological value is slightly lower.

The table shows data on the Update1 bread from the two different batches. Since data practically coincide, the two measurement results can be evaluated together. Due to the high histidine content of the extracted soya bean meal, the histidine content of the protein in the Update1 bread is slightly higher $(27 \mathrm{mg} / \mathrm{g})$ than that of the control bread. It has a slightly higher isoleucine content, which is a consequence of the egg white's higher isoleucine content. The leucine content is again a higher one as both soya protein and egg white have a higher leucine content than wheat protein. It has an approx. $80 \%$ higher lysine content than the control bread owing to the higher lysine content of the soya bean and egg white. Despite supplementation, its sulphur amino acid content (methionine, cystine) is not higher than that of the control bread due to the low sulphur amino acid content of the soya bean, which is, however, compensated by the sulphur amino acid content of the egg white, being well above the required level. On the whole, the sulphur amino acid content of the protein in the control bread and the Update1 bread may be considered identical.

The protein of the Update1 bread has a more than $10 \%$ higher aromatic amino acid (tyrosine, phenylalanine) content, while there is an even bigger difference, of almost 30\%, in the threonine content. This 30\% difference can also be observed in the tryptophan content, but the valine content of the 
two proteins shows only a slight difference in favour of the Update1 protein. (Regarding all amino acids, evaluation refers to the protein and the amount of amino acids. As the Update1 bread contains protein in an amount of almost three times the control bread, the sulphur amino acids are also present in the Update1 bread in a concentration almost three times higher, while in regard to the rest of the amino acids this difference can be even four- of fivefold.)

Using Morup and Olesen's (1976) method in our calculation, the biological values are as follows: gluten -47 , wheat flour -53 , soya bean meal -75 , and egg-white powder - 98. The biological value of the control bread was measured at 61 and that of the Update 1 bread at 75 . All in all, the wheat protein's biological value of 53 could be raised to 75 with the help of extracted soya bean meal, egg-white powder, and gluten supplementation, which is a more than $40 \%$ increase. (In all cases discussed, data refer to the protein.)

Comparing the protein content of the Update1 bread and the amino acid composition of the protein with data shown in tables $1-3$, we may state that $3-4$ slices of Update1 bread can cover most part (60-70\%) of an adult's daily essential amino acid requirements.

\subsection{Amount of the hydroxymethylfurfural}

Taking an average of five measurements, the hydroxymethylfurfural (HMF) content of the control bread was $0.98 \pm 0.05$ and that of the Update1 bread $4.56 \pm 0.34 \mathrm{mg} / \mathrm{kg}$. The examination of data using one-way variance analysis suggested significant differences, meaning that the hydroxymethylfurfural content increased in the breads consequent upon the addition of soya protein and egg white, which can contribute to imparting a flavour to the Update1 bread and increasing the volume of the compound with antioxidant properties, but, to a slight, almost insignificant degree, it can also reduce the amount of the available lysine.

\subsection{Sensory analysis results}

Based on the analyses carried out as prescribed by Codex Alimentarius (2004), only minimal differences could be observed concerning the following properties of the Update1 and the control bread: shape (typical of bread (loaf shape), regular, proportionately convex, not deformed), crust properties (typical of the particular type of bread; shiny, smooth or cracked; scattered and/or sliced; not split all the way, not sooty/soiled/burned/saturated/damaged), internal content (baked thoroughly; does not separate from the crust; the colour is 
typical of the flour used; the substance is consistent, flexible, and free of lumps; not lardy, sticky, crumbly, or falling apart; does not contain foreign substances), and taste and aroma (aromatic - typical of the particular type of bread, not having strange taste or odour). Although in conformity with the higher lysine and other amino acid content the taste and aroma of the Update1 bread differs from those of the traditional bread, this difference in taste and aroma is not a disagreeable one, and one can get used to it in a matter of days. A significant difference, however, was observed in the colour of the crust and the internal content, according to which the internal content of the Update1 bread had a darker shade, while the crust could come in hues that go all the way to dark brown, which is a consequence of the higher lysine content and the Maillard reaction during the baking process.

\section{Conclusions}

We determined the composition of ingredients used in the production of the Update1 bread, mixed them in appropriate proportions, and produced a type of flour with a composition whose caloric value was $1364 \mathrm{~kJ} / 100 \mathrm{~g}$, its fat content $1.4 \%$, of which the saturated fatty acid less than $0.5 \%$, its carbohydrate content $35.4 \%$, of which sugar $2.8 \%$, starch $32.6 \%$, fibre $14.4 \%$, protein $35.0 \%$, and salt $0.125 \%$. This mixture is a natural food ingredient with a protein content almost three times the fine-ground flour and a carbohydrate content decreased by half.

Wheat flour and gluten contained the smallest amounts of essential amino acids among the applied ingredients, yielding therefore the lowest biological value for the protein of wheat flour (53) and gluten (47). The high lysine and threonine content of the extracted soya bean meal is in line with expectations, but its sulphur amino acid content is rather moderate, and so the biological value of the protein is 75 . Due to its outstanding essential amino acid content, egg white disposes of the highest biological value (98), and thanks to its high methionine and cystine content, it serves as an excellent supplement to the low levels of sulphur amino acids in the soya and wheat protein as well as in gluten.

Comparing the amino acid composition of the protein in the control bread and the Update1 bread, we could establish that except for methionine and cystine, the protein of the Update1 bread contains substantially more essential amino acids, as a consequence of which the biological value of the control bread protein was 61 and that of the Update1 bread 75 . If we also take into account 
that the Update1 bread contains protein almost three times the control bread, which difference is therefore threefold in terms of sulphur amino acids and fourto fivefold regarding the rest of the amino acids, we may draw the conclusion that 2-3 slices of Update1 bread can cover $60-70 \%$ of an adult's daily essential amino acid requirements.

Based on the sensory analyses, in conformity with the higher lysine and other amino acid content, the taste and aroma of the Update1 bread, the colour and substance of the crust and internal content differ from those of the regular bread due to the applied supplements with a higher protein content.

In conclusion, we can say that the Update1 bread is a functional food with an outstanding biological value, a good taste, high protein and amino acid content, containing proteins almost three times and essential amino acids three to five times the traditional bread, and thus able to meet humans' amino acid requirements with a great efficiency.

\section{Acknowledgements}

The authors express their grateful thanks to the Scientific Research Department of the Sapientia Foundation for the financial support offered under Contract No 12/4/28.04.215.

\section{References}

[1] Cs. Albert, J. Csapó, Functional food production with the supplementation of wheat flour with lysine. Studia Universitatis Babeş-Bolyai, Seria Chemia. (2017a). Under publication.

[2] Cs. Albert, S. Gombos, R. V. Salamon, J. Prokisch, J. Csapó, Magas tápértékü funkcionális élelmiszer előállítása a búzaliszt lizin kiegészítésével [Production of high-nutritional-value functional food with the supplementation of the wheat flour with lysine]. Múszaki Szemle (Cluj-Napoca). (2017b). Under publication.

[3] Cs. Albert, S. Gombos, R. V. Salamon, J. Prokisch, J. Csapó, Production of high-nutritional-value functional food with the supplementation of the wheat flour with lysine. Acta Universitatis Sapientiae, Alimentaria, 10. (2017c). Under publication.

[4] A. A. Anton, K. A. Ross, O. M. Lukow, R. G. Fulcher, S. D. Arntfield, Influence of added bean flour (Phaseolus vulgaris L.) on some physical 
and nutritional properties of wheat flour tortillas. Food Chemistry, 109. (2008) 33-41.

[5] R. Civitelli, D. T. Villareal, D. Agneusdei, Dietary L-lysine and calcium metabolism in humans. Nutrition, 8. (1992) 400-404.

[6] J. Csapó, Zs. Csapóné Kiss, Cs. Albert, Sz. Salamon, Élelmiszerfehérjék minősitése. Scientia Kiadó, Cluj-Napoca, (2007) 1-506.

[7] J. Csapó, Zs. Csapóné Kiss, Biokémia - állattenyésztőknek. Mezőgazda Kiadó, Budapest, (2007) 1-378.

[8] J. Csapó, Zs. Csapóné Kiss, L. Babinszky, Z. Győri, L. Simonné Sarkadi, J. Schmidt, Élelmiszer- és takarmányfehérjék minősitése. Mezőgazda Kiadó, Budapest, (2006) 1-451.

[9] J. Csapó, Zs. Csapóné Kiss, Élelmiszerkémia. Mezőgazda Kiadó, Budapest, (2004) 1-492.

[10] M. E. A. El-Megeed, D. C. Sands, Methods and compositions for improving the nutritive value of foods. United States Patent 4897350. January 30. (1990).

[11] J. Figueron, G. Aeero, M. Vasco, A. L. Guzman, M. Flores, Nutritional quality of nistamal tortillas fortified with vitamins and soy proteins. International Journal of Food Science and Nutrition, 54. (2003) 189200.

[12] S. Karcz, Lysine fortification. Food and Nutritional Bulletin. Boston, 25. (2004) 107-143.

[13] D. D. Kitts, C. Hu, Biological and chemical assessment of antioxidant activity of sugar-lysine model Maillard reaction products. Annals of the New York Academy of Sciences, 1043. (2005) 501-512.

[14] M. Lindenmeier, T. Hofmann, Influence of baking conditions and precursor supplementation on the amounts of the antioxidant pronyl-Llysine in bakery products. Journal of Agricultural and Food Chemistry, 52. (2004) 350-354.

[15] J. Mauron, P. A. Finot, F. Mottu, Process for fortifying foodstuffs with pro-lysines. United States Patent 3993 795. November 23. (1976). 
[16] A. Mora-Aviles, B. Lemus-Flores, R. Miranda-Lopez, D. HernándezLópez, J. L. Pons-Hernandez, J. A. Acosta-Gallegos, Effects of common bean enrichment on nutritional quality of tortillas produced from nixtamalized regular and quality protein maize flours. Journal of the Science of Food and Agriculture, 87. (2007) 880-886.

[17] I. K. Morup, E. S. Olesen, New method for prediction of protein value from essential amino acid pattern. Nutrition, 12. (1976) 355-365.

[18] H. A. Muhammad, R. Taha, E Khalil, A. Inteaz, A. Ali, M. Nather, N. Mohammad, Effects of barley flour and barley protein isolate on chemical, functional, nutritional and biological properties of Pita bread. Food Hydrocolloids, 26. (2012) 135-143.

[19] L. Pauling, Case report: Lysine/ascorbate-related amelioration of angina pectoris. Journal of Orthomolecular Medicine, 6. (1991) 144146.

[20] J. Prokisch, Z. Csiki, Cs. Albert, J. Csapó, Magas lizintartalmú keksz előállítása és a lizin felszívódásának vizsgálata emberben [Production of high lysine content biscuit and examination of the absorption of lysine in human]. Müszaki Szemle (Cluj-Napoca), (2017b). Under publication.

[21] J. Prokisch, Z. Csiki, Cs. Albert, J. Csapó, Production of high lysine content biscuit and examination of the absorption of lysine in human. Acta Universitatis Sapientiae, Alimentaria, 10. (2017a) Under publication.

[22] M. Rath, Aszkorbátot és lizint tartalmazó szinergetikus készítmények extracelluláris mátrixdegeneráció ellen. P 0100188. 01. 16. (2001).

[23] C. M. Rossel, J. Bajerska, A. F. El Sheikha (eds), Bread and its fortification for nutrition and health benefits. Taylor \& Francis Group, Boca Raton, London, New York (2016).

[24] H. Tajammal, A. Shaid, A. K. Mushtaq, S. S. Nevin, Lysine fortification of wheat flour improves selected indices of the nutritional status of predominantly cereal-eating families in Pakistan. Food Nutr. Buletin, 25, 2. (2004) 114-122.

[25] S. T. Titcomb, A. A. Juers, Composition for preparing a high complete protein wheat bread. United States Patent 3995 065. November 30. (1976). 
[26] S. K. Tyagi, M. R. Manikantan, H. S. Oberoi, G. Kaur, Effect of mustard flour incorporation on nutritional, textural and organoleptic characteristics of biscuits. Journal of Food Engineering, 80. (2007) 10431050 .

[27] Z. Wenhua, Z. Fengying, Z. Ding, A. Yunqing, L. Ying, H. Yuna, G. Keyou G. S. S. Nevin, Lysine-fortified wheat flour improves the nutritional and immunological status of wheat-eating families in Northern China. Food and Nutrition Bulletin, 25, 2. (2004) 123-129.

[28] R. E. C. Wildman, Nutraceuticals and Functional Foods. Taylor \& Francis Group, Boca Raton, London, New York, (2007). 